\title{
A Magyar Királyi Pénzügyőrség teendői a katonai határőrizetre való áttérés időszakában.
}

A dualizmuskori magyar pénzügy bármely feladatkörének a vizsgálatakor elsőként magának a szakterületnek az Osztrák-Magyar Monarchia államapparátusában való elhelyezkedését célszerü behatárolni. Ennek az előfeltétele pedig a dualista államalakulat lényegének a meghatározása.

Álláspontom szerint az Osztrák-Magyar Monarchia két ország, a Magyar Királyság és az Osztrák Császárság olyan szövetsége volt, amelyben a társországok a szuverenitásuk körébe tartozó egyes témák önálló kezeléséről lemondtak annak érdekében, hogy azokat közösen intézhessék. Volt ugyan a dualisztikus államalakulatnak egy másik felfogása is, amely szerint a dualizmus nem más mint - a HABSBURG-birodalom eltérő történelmi múltú, gazdasági helyzetű és kulturális állapotú — két tartománycsoport belső ügyeinek egymástól eltérő intézése. A gyakorlatban azonban az elöbbi felfogás érvényesült, így azt tekintem mérvadónak. ${ }^{1}$

A közös ügyek rendszerét és azoknak a két társország általi kezelését, illetve abban az uralkodó helyét és szerepét a magyar és az osztrák országgyülés által külön-külön becikkelyezett kiegyezési törvényben foglaltak határozták meg. Ezek ugyan nem voltak egymás tükörfordításai, azonban tartalmukban teljes egészében megegyeztek. ${ }^{2}$

A közös ügyek - amelyet a magyar fél pragmatikus ügyeknek nevezett, mivel a kiegyezést magyar részről a Pragmatica Sanctio-ból vezették le ${ }^{3}$ - azaz a hadügy, a külügy és a finanszírozásukra szolgáló pénzügy tekintetében a magyar pénzügyi kormányzatnak nem volt feladata. E téren csupán — a delegációk által jóváhagyott és kvótabizottságok által meghatározott arányban — a közös költségvetés Magyarországra eső részét kellett biztosítania a magyar pénzügyi kormányzatnak.

A magyar pénzügyet a vám- és kereskedelmi szövetségböl fakadóan a vámok érintették. A vámterület és a vámtarifák egységesek voltak ugyan a többé-kevésbé tízévente megújított vám- és kereskedelmi szövetségből fakadóan. ${ }^{4}$ Mindkét társország azonban önálló vámhivatali rendszerrel rendelkezett, melynek a bevételeit a közös ügyek finanszírozására fordították. A vámbevételeit mindkét ország pénzügyi tárcája tárgyévenként utalta át a közös költségvetést kezelő közös pénzügyminisztérium számára. A két társországnak pedig a közös költségvetés vámbevételekkel csökkentett összegének a kvóta alapján ráeső részét kellett biztosítania. ${ }^{5}$

A Magyar Királyság pénzügyi kormányzatát még a közös pénzrendszer és a közös jegybank témája is érintette. Az Osztrák-Magyar Monarchia fizetőeszköze 1892-ig a forint, ezt követően pedig a korona, a váltópénz pedig a krajcár volt. A bankjegyek egyik oldala német, a másik oldala pedig magyar feliratot kapott és az Osztrák Császárság, valamint a Magyar Királyság címere is helyet kapott a bankjegyeken. A bankjegykibocsátó intézmény az Osztrák-Magyar Bank volt. A bank vezetésében pedig mindkét társország kormányának a delegáltjai helyet kaptak. ${ }^{6}$ Mindkét országban a pénzkibocsátás hagyományosan az uralkodói felségjogok közé tartozott. A pénz tehát formálisan nem az Osztrák Császárság, vagy a Magyar Királyság bocsátotta ki, hanem az osztrák császár, illetve a magyar király, amely tisztségeket azonban egy természetes személy azaz Ferenc József töltötte be.

Az adózás tekintetében is szükség volt a két ország közötti egyeztetésre. Az állami monopóliumot képező só és dohány értékesítése során keletkező jövedékek, valamint a pálinka-, sőr-, továbbá a cukoradót egységesítették a HABSBURG-birodalom mindkét felében már a kiegyezést követően. Ehhez kapcsolódott 1882-től az ásványolaj jövedék. ${ }^{7}$

Az állami monopóliumok és jövedékek egységesítése azonban nem tudta az adózás témáját megnyugtató módon rendezni. Gondot jelentett, hogy a fogyasztási adó ugyan a fogyasztót terhelte, de azt a termelö rótta le. Abban az esetben tehát, ha nem azonos országban került sor a termék elöállítására és eladására, akkor azon ország járt rosszul, ahol a terméket eladták. Ezért tehát az Osztrák-Magyar Monarchia piacát a két társország 1899-ben kartel-jelleggel feloszlatta meghatározva, hogy mely termékből mely ország milyen mennyiség előállítására jogosult. A sör, ásványolaj és cukor adója tekintetében pedig az Osztrák Császárság és a Magyar Királyság abban állapodott meg, hogy az egyik országban gyártott és a másik országban értékesített termék mennyiségének megfelelően az adóösszeget is átutalják a fogyasztó ország kincstárának.

A Magyar Királyi Pénzügyőrséget tehát a magyar pénzügyi igazgatásnak a duális állam speciális helyzetével összefüggésben álló teendői csupán áttételesen érintették. A testület a magyar or- 
szággyülés által az állami egyedáruságokról és jövedékekről szóló törvényekben foglaltaknak megfelelően látta el szolgálati feladatait. A testület szolgálatára és szervezetére vonatkozó szabályokat a kiegyezés nyomán létrehozták és azokat jogszabálygyüjtemény formájában közreadták. ${ }^{8}$

A Magyar Királyi Pénzügyőrség a kiegyezéssel újjászervezett polgári magyar állam új magyar szervezete volt a Magyar Királyi Pénzügyminisztérium kompetenciájába tartozóan. A Magyar Királyi Pénzügyőrségnek nem volt, nem lehetett elődszervezete a neoabszolutizmus pénzügyőrsége, hiszen a kiegyezés lényegét alkotta, hogy a magyar nemzet újra szabadon gyakorolhatta az államiságát, csupán a közös ügyeket intézte a dualizmus társországával közösen. Márpedig a pénzügyőrség nem tartozott a közös ügyek közé.

Nyilvánvaló volt azonban, hogy a rendiségi körülményeknek megfelelő pénzügyi hierarchia túlhaladottá vált, melyhez a kiegyezést követően nem lehetett visszatérni. A neoabszolutizmus testületeit pedig a magyar nemzet akkor sem fogadta volna el, ha a kormánynak lett volna ilyen szándéka. Mivel az új magyar pénzügyi kormányzatnak szüksége volt a polgári magyar állam viszonyainak megfelelő pénzügyőrségre, azonban ezen szervezet nem lehetett a magyar nemzetet elnyomó államhatalom, azaz a neoabszolutizmus pénzügyőrsége, ezért új pénzügyőri testületet állítottak fel a Magyar Királyi Pénzügyőrséget. ${ }^{9}$

Nem volt elég azonban az új szervezet létrehozása. A testület müködtetéséhez megfelelő képzettséggel és tapasztalatokkal rendelkező személyi állományra is szükség volt. A legészszerübb és a leggyorsabb megoldást az jelentette, hogy a neoabszolutista pénzügyőrség azon szakembereit vette át az új magyar testület, akik nem kompromitálódtak a magyar nemzet elnyomása során. Ezt az utat követte a LÓNYAY Menyhért által vezetett magyar pénzügyi tárca. Ebből a szemszögből vizsgálva érthető, hogy miért tartozott a frissen kinevezett magyar pénzügyminiszter első intézkedései közé a magyar szolgálati nyelvröl szóló utasítás. A neoabszolutizmus pénzügyőrségének a hivatalos nyelve ugyanis a német volt. A pénzügyőr szakemberek döntő többsége ezt a nyelvet beszélte. A jó szakember, de a magyar nyelvet nem, vagy alig beszélő pénzügyőr tisztek (tisztviselők) számára határidőt szabtak a magyar nyelv elsajátítására.

Így jött létre az új magyar polgári állam pénzügyőrségének a személyi állománya, akik már magyar szervezetben, a magyar nemzet érdekében látták el szolgálati feladataikat, azonban a szakemberek jelentős része - legalábbis kezdetben — még csupán törte a magyart. A Magyar Királyi Pénzügyőrség - annak ellenére, hogy szakembereinek jelentős része kezdetben nem, vagy alig beszélt magyarul - már nemzeti szervezet volt, hiszen a legitim magyar országgyülés által hozott törvények szerint müködött a magyar nemzet érdekében és a külsőségei tekintetében is a magyar jelleg dominált. ${ }^{10}$

A Magyar Királyi Pénzügyőrség a pénzügyi tárcán belül számos más hatósággal együttmüködve látta el a feladatait. A testületnek természetesen voltak saját teendői is, az állami monopóliumokkal, a jövedékekkel kapcsolatosan. Emellett azonban egyfajta pénzügyi rendőrségként is müködött. Tevékenységének lényegét a pénzügyi tárca feladatkörét sértő büncselekmények felderítése, megakadályozása, illetve megelőzése alkotta. Legalább ilyen nagy súllyal bírt azonban a tárcán belüli testületek tevékenységének szükség szerinti fegyveres segítése is.

A dualizmus időszakában minden tevékenységet, amelynek a teljesítéséhez fegyveres személyzetet vettek igénybe karhatalmi teendőnek neveztek függetlenül attól, hogy tényleges fegyverhasználatra sor került vagy sem. Elég volt a fegyveres személyzet közremüködése egy feladat végrehajtásában, azt már karhatalmi tevékenységnek tekintették még akkor is, ha konkrét fegyverhasználatra nem került sor. Karhatalmi cselekménynek számított az is, ha a tevékenység során csupán a fegyverhasználat lehetősége állt fenn. Karhatalmi tevékenységnek tekintették például azt is, hogy a bíróság idézésére meg nem jelent személyeket a bíróság csendőr járőrrel vezettette elö. Korunk csapaterőhöz kötött karhatalom fogalmához képest a karhatalomról alkotott korabeli felfogás igen távol állt. A korabeli fogalmak szerint tehát a pénzügyi tárcán belül a karhatalmi erőt a Magyar Királyi Pénzügyőrség biztosította. ${ }^{11}$

A Magyar Királyi Pénzügyőrség ezen képessége koránt sem volt elhanyagolható, hiszen a kormány szükölködött a közvetlen irányítása alatt álló rendvédelmi testületek tekintetében. A dualizmus időszakában csupán három állami rendőrség müködött a Magyar Királyságban. Ezek voltak a belügyi tárca irányítása alá tartozóan a fővárosi rendőrség (1872-től ideiglenesen, majd 1881-től véglegesen államosítva) ${ }^{12}$, a Magyar Királyi Határrendőrség (1906-tól) ${ }^{13}$, a Fiumei Magyar Királyi Állami Rendőrség (1916-tól). ${ }^{14}$ A Magyar Királyi Csendőrséget — ugyancsak a Magyar Királyi Belügyminisztérium felügyelete alá tartozóan - 1881-ben hozták létre ${ }^{15}$ és az évtized közepére épült ki az ország teljes vidéki területére kiterjedő szervezete. ${ }^{16}$ Országos fegyveres szervezetnek 
tekinthető még az 1867. III. 10-ével a Magyar Királyi Igazságügyi Minisztérium alárendeltségébe kerülő büntetés-végrehajtási intézetek fegyőri testülete (mai terminológiánk szerinti büntetésvégrehajtási testület), amely azonban kizárólag a börtönök területén volt alkalmazható. ${ }^{17}$

Emellett — a pénzügyi tárca alárendeltségében 1872-től 1886-ig müködött — a Magyar Királyi Vám- és Adóőrség amelynek az volt a feladata, hogy a volt katonai határőrvidék lakosságának a polgári életforma körülményeihez való visszatérését elősegítse. ${ }^{18} \mathrm{~A}$ központi államhatalom kompetenciájába tartozott még ugyan a Magyar Királyi Nemesi Testőrség (1760-1849, majd 1867-től újjászervezve) ${ }^{\mathbf{1 9}}$, a Magyar Királyi Darabont Testőrség (1904-től) ${ }^{20}$ és a Magyar Királyi Képviselőházi Örség (1912-től) $)^{21}$, valamint a Magyar Királyi Koronaőrség is. ${ }^{22}$ A testőrségeket, a korona- és a képviselőházi őrséget azonban az alapfeladatuktól eltérő teendők végrehajtására nem lehetett igénybe venni.

A Magyar Királyi Csendőrség létrehozásáig a kormánynak a Magyar Királyi Pénzügyőrségen kívül nem is állt a rendelkezésére más a közvetlen alárendeltségébe tartozó és az ország egész területére kiterjedő müködési területtel bíró rendvédelmi testület. Így jöhetett létre az a helyzet, hogy a határvonal örzését kezdetben nem is lehetett más magyar fegyveres szervezetre bízni, mint a Magyar Királyi Pénzügyőrségre. ${ }^{23} \mathrm{Az}$ önkormányzati rendőrségek ugyanis erre a feladatra teljességgel alkalmatlanok voltak. Ahány önkormányzati rendőrség müködött az országban annyi rendőrségi szabályzat volt érvényben. Ezen testületek egyenruhája is önkormányzatonként változott. A fegyverüket épedig a rendőrök önállóan szerezték be, ezért egységes fegyverzet sem jöhetett létre. ${ }^{24}$ Ennek ellenére a határmenti városok rendőrségeit bevonták a határőrizetbe, mégpedig annak a forgalomellenőrzési részébe. A határátkelőhelyekre — korabeli szóhasználat szerint a határkapukhoz — ugyanis a legközelebbi nagyobb város rendőrségének a személyi állományából kikülönített csoportot telepítettek a személyforgalom ellenőrzése céljából. ${ }^{25} \mathrm{Az}$ áruforgalmat a vámhivatalok ellenőrizték, amelyek a pénzügyi tárcán belül önálló hivatali rendszert alkottak. A vámhivatalnokok nem rendelkeztek fegyverrel. Müködésük fegyveres biztosítását - más pénzügyi szakhatósághoz hasonlóan — ha arra szükség volt, akkor a Magyar Királyi Pénzügyörség látta el. ${ }^{26}$

A határôrizet három ága — a határvonal őrzése, a határforgalom ellenőrzése és a határrend betartatása — közül tehát egyet, a határvonal őrzését a Magyar Királyi Pénzügyőrség valósította meg. A határőrizet másik részét a határforgalom ellenőrzését kétféle szervezet végezte. A személyforgalmat a határmenti városok önkormányzati rendörségeinek kikülönített csoportjai, az áruforgalmat pedig a vámhivatalok ellenőrizték. A határőrizet harmadik ágát a határrend betartatásának a teendőit pedig a vámhatármenti járások határmenti szolgabírói kirendeltségei látták el. ${ }^{27}$

Ily módon tehát a magyar határőrizet teendőit megosztották a magyar közigazgatás és rendvédelmi testületek azon szervezetei között, amelyek alapfeladatai a legközelebb álltak az adott részhatárőrizeti feladathoz, illetve a határmenti elhelyezkedésükből fakadóan eleve a helyszínen voltak találhatók. A négyféle szervezettípus - azaz a pénzügyőrség, a rendőrség, a vámhivatalok és a helyi közigazgatás - közül kettő, mégpedig a pénzügyőrség és a vámhivatalok a központi államhatalom közvetlen felügyelete alatt álltak. a másik két szervezet pedig, azaz a rendőrség és a határszéli szolgabírói kirendeltség önkormányzati kompetenciába tartozott. A négyféle szervezet közül csupán két szervezet, a pénzügyőrség és a rendőrség tekinthető fegyveres testületnek, bár a rendőrségek felfegyverzése napjaink elvárásaitól messze állt, azonban a személyi állomány kétség kívül rendelkezett valamilyen lőfegyverrel és azokat a köz érdekében jogi úton szabályozott keretek között használhatta is. A magyar határôrizetben szolgálatot teljesítő szervezettípusok közül tehát csupán kettő: a pénzügyőrség és a rendőrségek tartoztak a rendvédelmi szervezetek közé. ${ }^{28}$

Katonailag szervezett fegyveres örtestület kezdetben nem is volt a magyar határörizetet megvalósító szervezetek között. Később azonban — a Magyar Királyi Csendőrség létrehozása nyomán 1892-től a csendőrséget is bevonták a határőrizet határvonalörzési teendőibe. Így tehát a magyar határőrzés kétlépcsőssé vált, ahol az egyik lépcsőt a Magyar Királyi Pénzügyőrség azon szakaszai látták el, amelyek müködési területe érintkezett a Magyar Királyság vámhatáraival. A második lépcsőt pedig a Magyar Királyi Csendőrség azon határmenti őrsei alkották, amelyek örskörlete érintkezett Magyarország vámhatáraival. A pénzügyőr szakaszok és a határmenti csendőr őrsök személyi állományai egyaránt az egyéb szolgálati teendőik ellátása mellett végezték a határvonal őrzését. Az érintett csendőrségi és pénzügyőrségi szervezeti egységek személyi állományainak tagjai a határörzési szolgálati feladataik ellátásáért pótlékban részesültek, illetve az érintett szervezeti egységek létszáma általában néhány fővel több volt, mint a térségben szolgálatot teljesítő hasonló szervezeti egységek szokásos létszáma. ${ }^{29}$ 
Ezt a helyzetet módosította a Magyar Királyi Határrendőrség felállítása, mivel az új szervezet átvette a határmenti szolgabírói kirendeltségek és a határkapukhoz telepített kikülönített rendőri csoportok feladatköreit. Ezzel a határrend betartatásának és a határon áthaladó személyforgalom ellenőrzésének a témája önkormányzati kompetenciából a központi államhatalomnak közvetlenül alárendelt rendvédelmi testület hatáskörébe került. Ezen az sem változtatott, hogy a határforgalom ellenőrzését a határszéli csendőrség és a határrendőrség megosztva gyakorolta, mivel a távolsági határforgalmat a határrendőrség, a kishatárforgalmat pedig a határszéli csendőrség ellenőrizte. Emellett pedig a határrendőrségnek a teljes határőrizetre kiterjedő hatáskörrel a részhatárőrizeti feladatok felügyeletére és összehangolására kiterjedő hatásköre is volt, melynek eredményes végrehajtása érdekében — szükség esetén jogszabályokban meghatározott feltételek mellett — a határ mentén elhelyezkedő fegyveres rendvédelmi szervezeteket ideiglenesen is bevonhatta a határörizetbe. ${ }^{30}$

A XX. század első évtizedének a második felére tehát már kiérlelődött a dualizmuskori magyar határőrizeti rendszer. E struktúrában a határszéli csendőrség, mint a Magyar Királyi Csendőrség szakszolgálati ága — bár e kifejezést a vizsgált időszakban még nem használták — vett részt, mint a központi államhatalomnak közvetlenül alárendelt és katonailag szervezett fegyveres örtestület. Ugyancsak a határvonal örzésében vett részt a Magyar Királyi Pénzügyőrség, mint a központi államhatalomnak ugyan közvetlenül alárendelt, ám polgári fegyveres örtestületként. A határőrizet másik két ágát a határrend betartatását és a határforgalom ellenőrzését — pedig a határrendőrség végezte, mint ugyancsak a központi államhatalomnak közvetlenül alárendelt polgári fegyveres őrtestület. A határforgalom ellenőrzése azonban megoszlott — a személyforgalmat illetően - a határszéli csendőrség és a határrendőrség között, míg az áruforgalmat a vámhivatalok ellenőrizték. ${ }^{31}$ (I.sz. melléklet)

Álláspontom szerint indokolt a katonailag szervezett fegyveres őrtestület és a polgári fegyveres őrtestület korabeli terminológiák használata, mivel e kifejezések a polgári magyar állam időszakában a két testülettípus közötti eltérés lényegét fejezik ki. Nevezetesen a katonailag szervezett fegyveres őrtestület személyi állományának a tagjai személyükben katonának minősültek függetlenül attól, hogy a testület, ahol szolgálatot teljesítettek mely tárca irányítása alatt állt és milyen feladatrendszert látott el, ennek érdekében pedig milyen jogkörrel ruházták fel. A katonának minősülő személyi állománnyal rendelkező testületek tagjai személyükben a honvédelmi tárca kompetenciájába tartoztak, őket a katonákra általában vonatkozó jogosultságok megillették, illetve kötelezettségek terhelték. E személyi állományba tartozók katonai rendfokozatot viseltek, testületekben az aláés fölérendeltségi viszonyok katonaiak voltak.

Ezzel szemben a polgári fegyveres örtestületek személyi állománya nem minősült katonának. Személyükben annak a tárcának a kompetenciájába tartoztak, amely az öket foglalkoztató testületet irányította. E testületek tagjai nem katonai, hanem a testületi rangrendszer rendfokozatait viselték. E testületekben az alá- és fölérendeltségi viszonyok nem katonaiak, hanem hivatalnokiak voltak. A polgári fegyveres örtestületek mai fogalmaink szerinti tisztikara tisztviselőknek minősült és az elnevezésük is ennek megfelelő volt. ${ }^{32}$

A katonailag szervezett, továbbá a központi államhatalomnak közvetlenül alárendelt rendvédelmi testületek súlyának a dualizmuskori gyarapodása nem csupán a határörizetet, hanem a teljes magyar rendvédelmet is jellemezte.

A közigazgatás kívánatos fejlesztési irányáról a Magyar Királyságban a reformkorban elméleti vita folyt. A vita során két fő irányzat kristályosodott ki. A municipalisták az önkormányzat, a centralisták pedig a központisítás erősítésével képzelték el a magyar közigazgatás, azon belül pedig a magyar rendvédelem fejlesztését. Végülis a vita a municpálisok győzelméhez vezetett. Mivel pedig a gyülölt magyarellenes neoabszolutista rendszer is a centralizmus szellemében jött létre és müködött, ezért a kiegyezés után a municipalizmus szellemében láttak hozzá a polgári magyar állam közigazgatásának, azon belül pedig a rendvédelemnek az újjászervezéséhez. Azonban bármilyen szép - és föleg a közutálatnak örvendő neoabszolutizmus kori centralista gyakorlattal ellentétes - felfogás szerint szervezte újjá a magyar állam az új magyar rendvédelmet, az a gyakorlatban megbukott, mivel nem volt képes a polgári fejlődéshez szükséges és a lakosság által elvárt rendet kialakítani. A neoabszolutizmus által kivitelezett centralista rendvédelem iránti ellenszenv azonban oly erős volt a korabeli magyar közgondolkodásban, hogy a kormányzat kezdetben nem is gondolt a magyar rendvédelem centralista irányba mutató alakítására. E helyett — ideiglenes jelleggel úgynevezett királyi biztost neveztek ki azon vármegye csoport élére, amely a leginkább veszélyeztett helyzetbe került a közrendvédelem terén. Ilyen királyi biztos volt RÁDAY Gedeon, akit a délvidéki vármegye csoport élére teljhatalommal felruházva azért neveztek ki, hogy a rendet helyreállítsa. A királyi biztos szívós munkával és drákói módszerekkel vissza is állította a törvényes állapoto- 
kat. Amint azonban teljesítve feladatát megbízatását visszaadta, távozása nyomán újrarendeződött az anarchia. ${ }^{33}$

Nyilvánvaló volt tehát, hogy a magyar rendvédelmi modell reformra szorul, mivel még a királyi biztos közbiztonságot helyreállító ténykedése nyomán sem volt képes az anarchia visszarendeződését megakadályozni. Ekkor jutott TISZA Kálmán arra a felismerésre, hogy a magyar rendvédelmi modellt a centralizmus és a katonailag szervezett őrtestület aránya növekedésének az irányában kell fejleszteni. Ennek a felismerésnek a nyomán vette át a kormány a közös haderőtől az erdélyi és a horvátországi csendőr ezredeket ${ }^{34}$, majd hozta létre a Magyar Királyi Csendőrséget. ${ }^{35}$

Az önkormányzati túlsúlyú magyar rendvédelmi modell ütőképességének a növelése a katonailag szervezett fegyveres örtestület bevonásával, illetve a központi államhatalom közvetlen alárendeltségébe tartozó rendvédelmi erők gyarapításával 1881-ben elkezdődött. Sajnálatos módon azonban a rendőrségek tekintetében e folyamat lassan ment végbe és az I. világháború kitöréséig nem is zárult le. 1912-ben ugyan az országgyülés felszólította a belügyminisztert arra, hogy az új városi törvény tervezetének a létrehozása keretében alakítsák ki az államosított rendőrségre vonatkozó javaslatot is. A belügyi tárca ennek eleget is tett és a törvényjavaslatot 1914-ben benyújtotta az országgyülésnek. A honatyák azonban az indítványt átdolgozásra visszaadták. Közben azonban kitört az I. világháború, így a rendőrségek államosításának a témája lekerült a napirendről. Ebből fakadóan a világháború alatt olyan rendvédelmi modell múködött Magyarországon, amelyben az egyik pillértestület a 12000 fös Magyar Királyi Csendőrség katonailag szervezett fegyveres örtestületként, a központi államhatalom közvetlen felügyeletével müködött a Szent Korona alá tartozó vidéki területekre kiterjedő hatáskörrel. A korabeli magyar rendvédelmi modell másik pillértestülettípusát alkotó rendőrségeket magába foglalóan ugyancsak összességében mintegy 12000 fövel müködött, de nem a kormány, hanem az önkormányzatok alárendeltségében a városok hatósági területére kiterjedöen. ${ }^{36}$

A magyar rendvédelmi modell határörizeti részében ez a folyamat - a magyar rendvédelem egészéhez képest tízéves késéssel - 1891-ben kezdődött el a határszéli csendőrség létrehozásával. $^{37}$ a határörizetben azonban a folyamat gyorsabban ment végbe, mint a magyar rendvédelem összességében. 1906-ban ugyanis — a Magyar Királyi Határrendőrség felállításával — a határőrizetből az önkormányzati kompetenciába tartozó rendvédelmi testületek kikerültek. ${ }^{38}$

A magyar határőrizet tehát a XIX. század utolsó és a XX. század első évtizedében megújult. E folyamat során a Magyar Királyi Pénzügyőrség veszített a határörizetben betöltött súlyából. A pénzügyőrség ugyanis változatlan létszámmal látta el határőrizeti feladatait, miközben a határőrizetben résztvevő társ rendvédelmi szervezetek személyi állományának a létszáma a kiegyezéskorihoz képest jelentősen gyarapodott. A pénzügyőrség határőrizetben betöltött feladatköre sem változott meg, pedig a határőrizeti feladatok ellátásába belépő szervezetek jelentős hatáskört kaptak és a határmenti szervezeti egységeiket olyan szervezeti elemekkel erősítették meg, amelyeket kifejezetten a határőrizeti teendők eredményesebb megvalósítása érdekében hoztak létre. A határmenti pénzügyőr szakaszok hatásköre ezzel szemben nem gyarapodott és speciális szervezeti elemekkel sem bővült a szervezeti felépítésük. ${ }^{39}$

Ilyen helyzetben érte a magyar határőrizetet és annak részeként a Magyar Királyi Pénzügyőrség határmenti csapatait a katonai határőrizetre való áttérés előkészítése.

A Magyar Királyságban az országgyülés 1912-ben foglalta törvénybe a kivételes hatalomról szóló szabályozást, a közös hadsereg többszöri sürgetése során. ${ }^{40}$ Az Osztrák-Magyar Monarchia másik társországában a szabályozást jóval korábban megvalósították. A századfordulón Európa szinte valamennyi országában törvénybe foglalták a kivételes hatalom témáját. A kivételes hatalom alatt azt értették, melynek során — az eljövendő háború eredményes megvalósítása érdekében korlátozták az általános emberi jogokat, egyben pedig megteremtették annak a lehetőségét, hogy az emberi és anyagi forrásokat, kapacitásokat mozgósíthassák a hadicélok elérése érdekében. A kivételes hatalomról szóló szabályozás két féle típusa alakult ki. A brit minta szerint a kivételes hatalmat a kormány gyakorolta. Ezzel szemben a német minta szerint a kivételes hatalom gyakorlásának a kompetenciája a haderőt illette. Az Osztrák-Magyar Monarchia két társországa egymástól eltérő módon kívánta a kivételes hatalmat gyakorolni. Az Osztrák Császárságban a német mintát, a Magyar Királyságban pedig a brit mintát követték. Ebből fakadóan a Magyar Királyságban müködö rendvédelmi testületek a háború alatt sem kerültek a haderő felügyelete alá, hanem a kormány irányítása alatt maradtak a hadmüveleti területek kivételével. A hadmüveleti területek ugyanis — bár- 
hol helyezkedtek el az Osztrák-Magyar Monarchia területén — a haderő kompetenciájába kerültek. $^{41}$

A törvényi háttér tette lehetővé azt, hogy a magyar-román és a magyar-szerb határ — mint többé-kevésbé elöreláthatóan hadmüveleti terület — mentén a közös haderő területileg illetékes hadtestparancsnokságainak a vezérkari osztályai kidolgozzák a határmenti szervezetek katonai határőrizetbe való bevonásának a tervét. Ezekben a tervekben kaptak helyet a Magyar Királyi Pénzügyőrség vámhatár menti szakaszai is. ${ }^{42}$

A Magyar Királyság határainak a hossza — Horvátországot is beleszámítva — összesen 4166 km volt. Határőrizetet azonban csupán a 833,2 km hosszúságú magyar-román és a 458,26km hoszszú magyar-szerb határokon, összesen 1 291,46 km-en valósítottak meg. A Magyar Királyság és az Osztrák Császárság közötti 2083 km hosszú határszakaszon, továbbá a Magyar Királyság és Bosznia-Hercegovina 583,24 km hosszú határán határőrizetre nem volt szükség. ${ }^{43}$

A két társország, azaz az Osztrák Császárság és a Magyar Királyság közötti határok abszolút átjárhatóak voltak. Azokon bárki, bárhol és bármikor szabadon átléphetett. Ugyanez volt a helyzet az 1878-ban okkupált, majd 1908-annektált Bosznia-Hercegovina esetében is. A magyar törvényi szabályozás szerint minden magyar állampolgár szabadon utazhatott bárhová. Útlevélre abban az esetben volt szükség, ha a célország, vagy az útvonalba eső országok útlevélhez kötötték a területükre való belépést. Ebben az esetben pedig a magyar belügyminiszternek — a kölcsönösség elve alapján - intézkednie kellett arra vonatkozóan, hogy ezen országok polgárai is útlevéllel léphessenek a Magyar Királyság területére. ${ }^{44}$

Az útlevelet lényegében minden magyar állampolgárnak ki kellett állítani, ha azt kérte. Az útlevélkiadás is decentralizált volt, mivel a helyi hatóságok állították ki ezen utiokmányiokat. Csupán a jogerősen elítéltek — ha még nem töltötték le a büntetésüket — és a sorkatonai szolgálatot ellátók külföldre utazását korlátozta törvényi úton a magyar állam. Románia és Szerbia útlevélhez kötötte az országa területére való belépés és az Osztrák-Magyar Monarchia vámterületén is kívül estek. Ebből fakadóan e két határvonal őrzésére békeidőszakban is szükség volt. ${ }^{45}$

A háborús időszak katonai határőrizetre való áttéréséhez a határ menti erőforrásokat szervezeték meg, ennek részeként kaptak kulcsfontosságú szerepköröket a békehatárőrizetben résztvevő rendvédelmi testületek határ menti alakulatai. Erre jogalapot az teremtett, hogy ezen térségek egy esetleges fegyveres konfliktus létrejötte esetében nagy valószínüséggel hadmüveleti területekké válhattak. Az eredményes védekezés, illetve támadás előfeltételeinek az előkészítését pedig már békeidőszakban is el kellett kezdeni, mégpedig azon erökre támaszkodva, amelyek a helyszínen voltak. Így jöhetett létre az a helyzet, hogy a haderö a román és a szerb határ menti magyar rendvédelmi testületek tevékenységét megtervezte háború esetére és ezen tervben foglaltak megvalósításához a haderő részéről elvárhatóan szükséges személyi és tárgyi feltételeket is biztosítani igyekezett. ${ }^{46}$

A katonai határőrizetre való áttérés időszakában a Magyar Királyi Határrendőrségtől a határszéli csendőrséghez került át a magyar határőrizeti erők vezetésének a jogosultsága. A Magyar Királyi Csendőrség személyi állománya ugyanis - ellentétben a határrendőrség tagjaival — katonailag képzett volt és hadifegyverrel, azaz Mannlicher-karabéllyal is rendelkezett, amelyek használatában gyakorlott volt. A csendőrségen belüli függelmi viszonyok pedig katonaiak voltak. A határrendőrség személyi állománya számára, ugyan rendszeresítettek egységes szolgálati lőfegyvert, ezek azonban csupán pisztolyok voltak, mivel 1912-ben — amikor a határrendőri őrsöket megszüntették - a karabélyokat átadták a szolgálati feladataik döntő többségét átvevő határszéli csendőr őrsöknek. A határrendörségen belüli fegyelmi viszonyok hivatalnokiak voltak. ${ }^{47}$

A határszéli csendőrségen kívül a Magyar Királyi Pénzügyőrség határ menti alakulatai az egyetlen olyan magyar rendvédelmi testülethez tartoztak, amelynek a személyi állománya részére hadifegyvernek minősülő Mannlicher-karabélyokat rendszeresítettek. Ebből fakadóan az érintett pénzügyőrök katonai határőrizetbe való bevonásáról nem lehetett lemondani. A haderő csapatainak a határra való felvonulásáig szükség volt a térségben élő valamennyi hadra fogható emberre. Ebből fakadóan a behívási rendszert is úgy alakították, hogy a hadköteles és kiképzett helyi férfi lakosság tagjainak ne kelljen az ország belsejében kialakított bázisokra utazniuk a felszerelésük felvétele és a hadrendi besorolásuk érdekében. A helyi hadkötelesek hadfelszereléseiből, amit lehetett kiosztottak otthoni tárolásra, a többit pedig a kibővített határszéli csendör őrsök épületegyütteseiben helyezték el.

A mozgósításkor a határmenti hadköteleseknek a határszéli csendőrség őrseire kellett bevonulniuk és a hadifelszerelésük még hiányzó részét is ott kapták meg, egyben pedig az őrsparancsnokok alárendeltségébe kerültek. Az őrs-parancsnokok voltak ugyanis a müködési területü- 
kön a katonai határörizet felelős parancsnokai mindaddig, amíg a haderő csapatai fel nem vonultak az érintett terepszakaszra, amikor az irányítást a hadsereg tisztjei vették át. Ebbe a rendszerbe illeszkedett a határ menti pénzügyőr alakulatokban szolgálatot teljesítő pénzügyőrök katonai határőrizetbe történő bevonása. ${ }^{48}$

A határ menti pénzügyőrök mozgósításkor automatikusan népfölkelöi állományba kerültek, ily módon a többi behívott polgári tartalékossal azonos jogállásúvá váltak. A jogi helyzetük átminősítése azonban koránt sem volt elég ahhoz, hogy a katonai határőrizetben eredményesen részt vehessenek. Ehhez alapvetően három alapfeltételt kellett biztosítani. A katonai kiképzettségüket és a fizikális állapotukat az elvárható szintre kellett hozni, a felszereltségüket hadihasználható állapotúvá kellett alakítani, továbbá a katonai hatérórizet struktúrába kellett helyezni az érintett pénzügyőröket.

E célok elérése érdekében a pénzügyőrség illetékesei az érintett határon szolgálatot teljesítő személyi állomány felszerelését rendszeresen ellenőrizték, a szükségessé váló cseréket haladéktalanul megvalósították. A vámvonalak mentén elhelyezkedő pénzügyőr szakaszok kötelékében szolgálatot teljesítő személyi állományt pedig 35 évesnél fiatalabb ép és egészséges hadiszolgálatra alkalmas pénzügyőrökkel töltötték fel. ${ }^{49}$

A haderő az érintett pénzügyőrök számára kiképzőbázisain rendszeres továbbképzést biztosított, melynek keretében a fegyverhasználati és a harcászati eljárásokban való képességeket alakították ki, illetve gyarapították.

Szükség volt ezekre az előkészítési teendőkre, mivel a katonai határőrizetre való áttéréstől alapjaiban változott meg a békehatárőrizeti metodika. Békeidőszakban ugyanis általában két fős járőrök döntően a csempészek valószínüsíthető mozgási helyén és idejében teljesítettek szolgálatot, többnyire többvonalas elhelyezkedéssel. E járörök egymástól látó és halló távolságban tevékenykedtek, így szükség esetén egymás segítségére siethettek. Szigorúan tilos volt a járőröknek a határon átlépni, vagy átlőni, egyben pedig a fegyvereik használatára vonatkozóan szigorú előírások szerint kellett eljárniuk. ${ }^{50}$

A katonai határőrizetre való áttéréstől a járőrök sűrüsége a békeidőszakhoz képest jelentősen gyarapodott és a járörökben szolgálatot ellátók száma is 6-12 före emelkedett. Emellett a szokásos csempész utakon kívül szinte minden a határon átvezetö ösvényt szemmel kellett tartaniuk, mivel ezen időszakban az ellenség célja már a magyar erők határvonalra történő felfejlődésének a nehezítése volt. Ennek érdekében pedig a közlekedési és hírközlési infrastruktúra, valamint a csapatok elhelyezésére is alkalmas építmények rongálása volt a cél. A honi határőrizeti erőknek tehát az ilyen szabotázs jellegü akciók kivédésére kellett törekedniük, illetve hasonló akciókat kellett a határ túloldalán megvalósítaniuk. ${ }^{51}$

Az ellenséges romboló akciók kivédése érdekében a határ mentén a határszéli csendőrség vezetésével meg kellett szervezni a honi erők felfejlődése legfontosabb eszközének a vasútnak a védelmét is. Ennek érdekében úgynevezett „pályaudvari őrségeket” és „,vasúti mütárgy őrségeket” — ez utóbbiak látták el a vasúti pályák őrzését —, valamint „,vonalszakasz tartalékokat” hoztak létre. A tartalékokat akkor vetették be, ha a rájuk bízott vasúti pályákat, mütárgyakat és pályaudvarokat támadás érte. ${ }^{52}$

A pénzügyőröknek fontos szerepük volt a katonai határőrizet teendőiben, mivel nélkülözhetetlen helyismerettel rendelkeztek. A helyismeret fontossága nyilvánvaló, ha figyelembe vesszük, hogy a katonai határőrizetért felelős csendőr őrs-parancsnokok számára kiadott irányelvek egyik fontos szempontja volt azon tétel, mely szerint a járőrök és őrségek tagjai között mindig lennie kellett legalább egy főnek, aki kiváló helyismerettel rendelkezett. ${ }^{53}$

Összességében tehát megállapítható, hogy a Magyar Királyi Pénzügyőrség vámhatárvonalat is érintő müködési területtel rendelkező szakaszainak a személyi állománya békeidőszakban és háborúban egyaránt fontos feladatokat látott el a határvonal őrzésében. A testületnek ugyan a határörizetben nem alakult ki vezető szerepe, a teendői azonban nélkülözhetetlenek voltak. 
$\frac{\text { Jegyzetek: }}{1}$

${ }^{1}$ GALÁNTAI: 89-91.p. + 138-160.p.

${ }^{2} 1867 /$ XII.tc. ; Nr.146/1867.

${ }^{3} 1723 /$ I.tc. ; 1723/II.tc.

${ }^{4}$ 1867/XVI.tc. ; 1878/XX.tc. ; 1878/XXI.tc. ; 1882/XVI.tc. ; 1887/XXIV.tc. ; 1887/XXV.tc. ; 1889/XVI.tc. ; 1897/VIII.tc. ; 1898/I.tc. ; 1899/XXX.tc. ; 1907/LIII.tc. ; 1917/XVII.tc.

${ }^{5}$ GalÁNTAI: 125-128.p.

${ }^{6}$ Loc.cit. 134-135.p.

${ }^{7} 1868$ /XI.tc. ; 1868/XIV.tc. ; 1868/XVI.tc. ; 1868/XIX.tc. ; 1868/XX.tc. ; 1882/XVIII.tc.

${ }^{8}$ A Magyar Királyi Pénzügyörség szervezete és szolgálata iránti szabályok.

${ }^{9}$ CIEGER: 1292.p.

${ }^{10}$ SALAMON: 170-183.p.

11 PARÁDI: Rendvédelem karhatalom 1867-1945. ; PARÁDI: Karhatalom a polgári magyar állam rendvédelmében 1867-1945. ; VEDÓ: A Magyar Királyi Csendőrség karhatalmi tevékenységének szabályozása a dualizmus idején. ; VEDÓ: A Magyar Királyi Csendőrség karhatalmi fellépésének gyakorlata.

12 1881/XXI.tc.

13 1903/VIII.tc.

14 1916/XXXVII.tc.

15 1881/II.tc. ; 1881/III.tc.

${ }^{16}$ PARÁDI: A Magyar Királyi Csendőrség. Az első magyar polgári, központositott közbiztonsági örtestület 1881-1945.

17 EsTóK: A polgári magyar állam büntetés-végrehajtásának egyenruházata és rangrendszere 1867-1945. 28-54.p. ; Idem: A büntetés-végrehajtás függelmi viszonyrendszerének, felügyeletének története 1867-1990 között. 28-54.p.

${ }^{18}$ PARÁDI: A dualizmuskori magyar rendvédelem. 66-79.p. ; Idem: A polgári magyar rendvédelem a XIX-XX. században. 60-72.p. ; Idem: A dualizmuskori és a két világháború közötti Magyar Királyság határőrizete. 71-76.p.ü

${ }^{19}$ HeLlebront: 11.p.

${ }^{20}$ PARÁDI: Az államfő testőrségei az Osztrák-Magyar Monarchiában. 155-158.p. ; Idem: Rendvédelmi testületek a polgári magyar állam időszakában 1867-1919. 121-132.p.

21 Tо́тн: 36-41.p. ; 1912/LXVII.tc.

${ }^{22}$ FAZAKAS - HEGEDÜS - HENNEL: 122-129.p.

${ }^{23}$ PARÁDI: A dualizmuskori és a két világháború közötti Magyar Királyság határörizete. op.cit. 71-72.p.

${ }^{24}$ Idem: Az Osztrák-Magyar Monarchia magyarországi rendőrségei 1867-1919. 97-101.p.

${ }^{25}$ Idem: A dualista Magyarország határörizeti rendszerének kialakulása. 44-51.p.

${ }^{26}$ Idem: A Magyar Királyi Pénzügyminisztérium határőrizeti feladatai az Osztrák-Magyar Monarchia magyarországi vámhatárain 1867-1914. 177-196.p.

${ }^{27}$ Idem: A magyar határörizet 1867-1945. 11-35.p.

${ }^{28}$ Idem: A katonailag szervezett őrtestület és a polgári őrtestület. 77-80.p.

${ }^{29}$ Idem: Nemzeti határörizetünk polgári szakasza. 141-148.p. + 153.p.

${ }^{30}$ Idem: A polgári magyar állam első határőrizeti szakszerve a Magyar Királyi Határrendőrség 1906-1914. ； Idem: A Magyar Királyi Csendörség határőrizeti feladatai 1891-1914.

${ }^{31}$ Idem: Határrendőrség a történelmi Magyarországon 1906-1918. 43-50.p. + 56.p.

${ }^{32}$ Idem: A katonailag szervezett őrtestület és a polgári őrtestület. op.cit.

${ }^{33}$ CsAPÓ: Ráday Gedeon és a szegedi királyi biztosság. A betyárvilág felszámolása.

${ }^{34} \mathrm{Idem}:$ A Magyar Királyi Csendörség története 1881-1914. 14-19.p.

${ }^{35}$ 1881/II.tc. op.cit. ; 1881/III.tc. op.cit.

${ }^{36}$ PARÁDI: A hátország rendvédelme 108-119.p.

3750 431/1891. (VII. 1.) BM.r.

38 1903/VIII.tc. op.cit. ； 5692/1905. (XII.29.) ME.r. op.cit. ； $91000 / 1905$. (XII. 29.) BM.kr.

${ }^{39}$ PARÁDI: A dualizmuskori magyar rendvédelem és határőrizet. A Magyar Királyi Határrendőrség.

40 1912/LXIII.tc.

${ }^{41}$ Mezey Barna: A kivételes hatalom. 4-6.p. ； Idem: Az első világháború jogi törvényhozói előkészítése: A kivételes hatalomról szóló 1912. évi 63. törvénycikk. 11-18.p.

42 PARÁDI: Áttérés a háborús határőrizetre az első világháború előtt. 13-16.p.

${ }^{43}$ Palotás ; PARÁdi — Suba — Vedó: 30.p.

44 1903/VI.tc.

${ }^{45}$ SOM

${ }^{46}$ PARÁDI: Áttérés a háborús határőrizetre az első világháború előtt. op.cit. 13-16.p.

${ }^{47}$ Idem: A Magyar Királyi Csendőrség határőrizeti szolgálata. 77-81.p.

${ }^{48}$ PARÁDI: Áttérés a háborús határőrizetre az első világháború előtt. op.cit. 13-16.p.

${ }^{49}$ Loc.cit.

${ }^{50}$ Loc.cit.

${ }^{51}$ Idem: A dualista Magyarország határőrizete 1867-1914. 117.p.

${ }^{52}$ Loc.cit. 118-120.p.

${ }^{53}$ Loc.cit. 


\section{Forrás-és irodalomjegyzék (a jegyzetekben alkalmazott röviditések oldása):}

\section{MONOGRÁFIÁK, KISMONOGRÁFIÁK ÉS HASONLÓ JELLEGÜ KÖTETEK}

CsAPÓ: A Magyar Királyi Csendörség története 1881-1914.

(34.;)

CsAPÓ: Ráday Gedeon és a szegedi királyi biztosság. A betyárvilág felszámolása.

(33.;)

GALÁNTAI

$(1 . ; 5 . ; 6 . ;)$

HELLEBRONTH

(19.;)

FAZAKAS - HEGEDŰS - HENNEL (22.;)

PALOTÁS

(43.;)

PARÁDI: A Magyar Királyi Csendörség. Az első magyar polgári, központositott közbiztonsági örtestület 18811945.

(16.;)

PARÁdI — SUBA — Vedó

(43.;)

SoM

(45.;)

\section{TANULMÁNYOK}

Cieger

(9.;)

EsTóK: A büntetés-végrehajtás függelmi viszonyrendszerének, felügyeletének története 1867-1990 között. (17.;)

EsTóK: A polgári magyar állam büntetés-végrehajtásának egyenruházata és rangrendszere 1867-1945.

(17.;)

MeZEY: A kivételes hatalom. $(41 . ;)$

MEZEY: Az első világháború jogi törvényhozói előkészítése: A kivételes hatalomról szóló 1912. évi 63. törvénycikk.

(41.;)

PARÁDI: A dualista Magyarország határörizeti rendszerének kialakulása. (25.;)
Csapó Csaba: A Magyar Királyi Csendőrség története 1881-1914. Pécs, 1999, Pro Pannónia Kiadói Alapítvány. 186 p. HU-ISBN 9639079405. /Pannónia Könyvek./ HU-ISSN 0237-4277.

Csapó Csaba: Ráday Gedeon és a szegedi királyi biztosság. A betyárvilág felszámolása. Pécs, 2007, Pro Pannónia Kiadói Alapítvány. 204 p. HU-ISBN 978963949887 7. /Pannónia Könyvek./ HU-ISSN 0237-4277.

GalÁNTAI József: A Habsburg-monarchia alkonya. Osztrák-magyar dualizmus 1867-1918. Budapest, 1985, Kossuth. 387 p. HU-ISBN 96309 25893.

Tisza-beői HelleBronth Kálmán et al. (szerk.): A magyar testőrségek névkönyve 1760-1918. Budapest, 1939, Stádium Sajtóvállalat Részvénytársaság. $543 \mathrm{p}$.

FazAKas László - Hegedüs Ernő - Hennel Sándor: A Szent Korona örzése. A koronaőrök, a koronaőrség. Budapest, 2002, Heraldika. 286 p. HU-ISBN 9639204021.

PALOTÁs Zoltán: A trianoni határok. Budapest, 1990, Interedition Kiadó. 93 p. HU-ISBN 9630262150.

PARÁDI József: A Magyar Királyi Csendörség. Az első magyar polgári, központositott közbiztonsági őrtestület 1881-1945. Budapest, 2012, Szemere Bertalan Magyar Rendvédelem-történeti Tudományos Társaság. 281 p. HU-ISBN 978963084794 0. /A magyar rendvédelem-történet öröksége, 2./ HU-ISSN 2062-8447.

PARÁDI József - SuBA János - Vedó Attila: A magyar-román határ és örzése 1867-1918. Budapest, 2014², Szemere Bertalan Magyar Rendvédelem-történeti Tudományos Társaság. 172 p. HU-ISBN 9789638982858. /A magyar rendvédelem-történet öröksége, 3./ HU-ISSN 2062-8447.

- Som Krisztián: A magyar úti okmányok 1848-2012. Budapest, 2014, Nemzetbiztonsági Szakszolgálat - Szemere Bertalan Magyar Rendvédelem-történeti Tudományos Társaság. 337 p. HU-ISBN 9789638982834. /Segédtudományok a magyar rendvédelem-történet szolgálatában, 1./ HUISSN 2064-5333.

- Cieger András: A számok szorításában. Lónyay Menyhért pénzügyminisztersége 1867-1870. Századok, CXXXVI.évf. (2002) 6.sz. 12951330.p. HU-ISSN 0039-8098.

EsTóK József: A büntetés-végrehajtás függelmi viszonyrendszerének, felügyeletének története 1867-1990 között. Börtönügyi Szemle, XXXII.évf. (2013) 4.sz. 28-54.p. HU-ISSN 1417-4758.

EsTóK József: A polgári magyar állam büntetés-végrehajtásának egyenruházata és rangrendszere 1867-1945. Rendvédelem-történeti Füzetek (Acta Historiae Praesidii Ordinis), XXVII.évf. (2017) 53.sz. 15-32.p. HUISSN 1216-6774.

Mezey Barna: A kivételes hatalom. Rendvédelem-történeti Füzetek (Acta Historiae Preasidii Ordinis), IV.évf. (1994) 5.sz. 4-6.p. HU-ISSN 1216-6774. A tanulmány korábbi változata 1993. szeptember 21.-én Budapesten hangzott el a Szemere Bertalan Magyar Rendvédelem-történeti Tudományos Társaság által szervezett rendvédelem-történeti tudományos konferenciasorozatnak a „Háború, forradalom, trianon” címü V. konferenciáján. A publikált tanulmány az előadás javított, bővített és átdolgozott változata.

MeZey Barna: Az első világháború jogi törvényhozói előkészítése: A kivételes hatalomról szóló 1912. évi 63. törvénycikk. 11-18.p. In ÁDÁM János - Seges Vladimir - Pallai László et al. (szerk.): Első világháború a Kárpátokban. Prvá svetová vojna v karpatoch. Перша світова війна в карnamax.] Eperjes, 2016, Eperjesi Egyetem. 336 p. SK-ISBN 97880555 17179.

PARÁDI József: A dualista Magyarország határőrizeti rendszerének kialakulása. Belügyi Szemle, XXX.évf. (1982) 10.sz. 44-51.p. HU-ISSN 0133-6738. 
PARÁDI: A polgári magyar állam első határörizeti szakszerve a Magyar Királyi Határrendőrség 1906-1914.

(30.;)

PARÁDI: A Magyar Királyi Csendőrség határörizeti feladatai 1891-1914.

(30.;)

PARÁDI: A Magyar Királyi Pénzügyminisztérium határőrizeti feladatai az Osztrák-Magyar Monarchia magyarországi vámhatárain 1867-1914. (26.;)

PARÁDI: Áttérés a háborús határörizetre az első világháború előtt. $(42 . ; 46 . ; 48 . ; 49 . ; 50 . ;)$

PARÁDI: A magyar határörizet 18671945.

(27.;)

PARÁdI: Az Osztrák-Magyar Monarchia magyarországi rendőrségei 18671919.

PARÁDI: A dualizmuskori magyar rendvédelem és határörizet. A Magyar Királyi Határrendőrség. (39.;)

PARÁDI: A dualizmuskori magyar rendvédelem.

(18.;)

PARÁDI: A polgári magyar rendvédelem a XIX-XX. században.

(18.;)

PARÁdi: A Magyar Királyi Csendőrség határőrizeti szolgálata.

(47.;)
PARÁDI József: A polgári magyar állam első határőrizeti szakszerve a Magyar Királyi Határrendőrség 1906-1914. Hadtörténelmi Közlemények, CI.évf. (1986) 3.sz. 541-570. p. HU-ISSN 0017-6540.

PARÁDI József: A Magyar Királyi Csendőrség határőrizeti feladatai 1891-1914. Hadtörténelmi Közlemények, CIII.évf. (1988) 1.sz. 56-92.p. HU-ISSN 0017-6540.

- PARÁDI József: A Magyar Királyi Pénzügyminisztérium határőrizeti feladatai az Osztrák-Magyar Monarchia magyarországi vámhatárain 18671914. Hadtörténelmi Közlemények, CIV.évf. (1989) 2.sz. 177-196.p. HUISSN 0017-6540.

PARÁDI József: Áttérés a háborús határőrizetre az első világháború előtt. Rendvédelemtörténeti Füzetek (Acta Historiae Praesidii Ordinis), IV.évf. (1994) 5.sz. 13-17.p. HU-ISSN 1216-6774. A tanulmány korábbi változata 1993. szeptember 21-én Budapesten hangzott el a Szemere Bertalan Magyar Rendvédelem-történeti Tudományos Társaság által szervezett rendvédelem-történeti tudományos konferenciasorozatnak a „Háború, forradalom, trianon" címü $\mathrm{V}$. konferenciáján. A publikált tanulmány az elöadás javított, bővített és átdolgozott változata.

PARÁDI József: A magyar határörizet 1867-1945. Határőrségi Tanulmányok, V.évf. (1997) 1. sz. különszáma. 11-35. p. HU-ISSN —

PARÁDI József: Az Osztrák-Magyar Monarchia magyarországi rendőrségei 1867-1919. Rendvédelem-történeti Füzetek (Acta Historiae Praesidii Ordinis), XI.évf. (2005) 13.sz. 97-104.p. HU-ISSN 1216-6774. A tanulmány korábbi változata 2000. március 19-én, Párizsban hangzott el a Szemere Bertalan Magyar Rendvédelem-történeti Tudományos Társaság által szervezett rendvédelem-történeti tudományos konferenciasorozatnak „A közbiztonság közös európai örökségünk” címü XIII. konferenciáján. A publikált tanulmány az előadás javított bővített és átdolgozott változata.

PARÁDI József: A dualizmuskori magyar rendvédelem és határőrizet. A Magyar Királyi Határrendörség. Határrendészeti Tanulmányok, III.évf. (2006) 1.sz. 5-46.p. HU-ISSN 1786-2345. A tanulmány korábbi változata 2006. január 17-én Budapesten hangzott el a Szemere Bertalan Magyar Rendvédelem-történeti Tudományos Társaság és a Határőrség Országos Parancsnoksága közös szervezésében megvalósított konferencián. „Az ezeréves magyar rendvédelem" című XIV. konferenciáján. A publikált tanulmány az előadás javított, bővített és átdolgozott változata.

PARÁDI József: A dualizmuskori magyar rendvédelem. Rendvédelemtörténeti Füzetek (Acta Historiae Praesidii Ordinis), XVIII.évf. (2010) 21.sz. 66-84.p. HU-ISSN 1216-6774. A tanulmány korábbi változata 2007. október 5-én Budapesten hangzott el, a Szemere Bertalan Magyar Rendvédelem-történeti Tudományos Társaság által szervezett rendvédelemtörténeti tudományos konferenciasorozatnak „A rendvédelem fejlödése a XIX-XX. században" című XXI. konferenciáján. A publikált tanulmány az előadás javított, bővített és átdolgozott változata.

PARÁDI József: A polgári magyar rendvédelem a XIX-XX. században. Rendvédelem-történeti Füzetek (Acta Historiae Praesidii Ordinis), XIX.évf. (2010) 22.sz. 60-76.p. HU-ISSN 1216-6744. A tanulmány korábbi változata 2008. október 10.-én Budapesten hangzott el, a Szemere Bertalan Magyar Rendvédelem-történeti Tudományos Társaság által szervezett rendvédelem-történeti tudományos konferenciasorozatnak „Másfél évszázad rendszerváltozásainak hatásai a nemzeti rendvédelmünkre" címü XXII. konferenciáján. A publikált tanulmány az előadás javított, bővített és átdolgozott változata.

PARÁDI József: A Magyar Királyi Csendőrség határőrizeti szolgálata. Rendvédelem-történeti Füzetek (Acta Historiae Praesidii Ordinis), XIX.évf. (2010) 22.sz. 77-91.p. HU-ISSN 1216-6774. A tanulmány korábbi változata 2008. október 10-én Budapesten hangzott el, a Szemere Bertalan Magyar Rendvédelem-történeti Tudományos Társaság által szervezett magyarrendvédelem-történeti tudományos konferencia-sorozatnak a „Másfél évszázad rendszerváltozásainak hatásai a nemzeti rendvédelmünkre" címü XXII. konferenciáján. A publikált tanulmány az előadás javított, bővített és átdolgozott változata. 
PARÁDI: Rendvédelem karhatalom 1867-1945.

(11.;)

PARÁDI: Nemzeti határőrizetünk polgári szakasza.

PARÁDI: Az államfö testőrségei az Osztrák-Magyar Monarchiában. (20.;)

PARÁDI: Rendvédelmi testületek a polgári magyar állam időszakában 1867-1919.

(20.;)

PARÁDI: A dualizmuskori és a két világháború közötti Magyar Királyság határőrizete.

(18.;23.;)

PARÁDI: A hátország rendvédelme 1914-1918.

(36.;)

PARÁDI: A katonailag szervezett őrtestület és a polgári őrtestület. (28.;32.;)

PARÁDI: Határrendőrség a történelmi Magyarországon 1906-1918.

(31.;)

PARÁDI: Karhatalom a polgári magyar állam rendvédelmében 1867-1945.

(11.;)

SALAMON

$(10 ;)$

То́тн

(21.;)
PARÁDI József: Rendvédelem karhatalom 1867-1945. Rendvédelemtörténeti Füzetek (Acta Historiae Praesidii Ordinis), XX. évf. (2011) 23. sz. 111-123.p. HU-ISSN 1216-6774. A tanulmány korábbi változata 2009. október 9.-én Budapesten hangzott el, a Szemere Bertalan Magyar Rendvédelem-történeti Tudományos Társaság által szervezett rendvédelemtörténeti tudományos konferenciasorozatnak „A kiegyezéstöl az ezredfordulóig felszámolt országos hatáskörü magyar rendvédelmi testületek." címü XXIII. konferenciáján. A publikált tanulmány az előadás javított, bővített és átdolgozott változata.

PARÁDI József: Nemzeti határőrizetünk polgári szakasza. Rendvédelemtörténeti Füzetek (Acta Historiae Praesidii Ordinis), XXIII. évf. (2013) 27-28-29-30.sz. 141-154.p. HU-ISSN 1216-6774. A tanulmány korábbi változata 2011. november 11-én, Budapesten hangzott el a Szemere Bertalan Magyar Rendvédelem-történeti Tudományos Társaság által szervezett rendvédelem-történeti tudományos konferenciasorozatnak a „,Militarizmus és demilitarizmus a XIX-XX. századi magyar rendvédelemben" címü XXVI. konferenciáján. A publikált tanulmány az előadás javított, bővített és átdolgozott változata.

PARÁDI József: Az államfő testőrségei az Osztrák-Magyar Monarchiában. Rendvédelem-történeti Füzetek (Acta Historiae Preasidii Ordinis), XXIII.évf. (2013) 27-28-29-30.sz. 155-160.p. HU-ISSN 1216-6774. A tanulmány korábbi változata 2011. november 11-én, Budapesten hangzott el a Szemere Bertalan Magyar Rendvédelem-történeti Tudományos Társaság által szervezett rendvédelem-történeti tudományos konferenciasorozatnak a „Militarizmus és demilitarizmus a XIX-XX. századi magyar rendvédelemben" című XXVI. konferenciáján. A publikált tanulmány az előadás javított, bővített és átdolgozott változata.

PARÁDI József: Rendvédelmi testületek a polgári magyar állam időszakában 1867-1919. Rendvédelem-történeti Füzetek (Acta Historiae Preasidii Ordinis), XXIII. évf. (2013) 31-32-33-34.sz. 121-146.p. HU-ISSN 1216-6774. A tanulmány korábbi változata 2014. február 21-én, Budapesten hangzott el, a Szemere Bertalan Magyar Rendvédelem-történeti Tudományos Társaság által szervezett rendvédelem-történeti tudományos szimpozionsorozatnak „, A kivételes hatalom és a közbiztonság” című XIV. szimpozionján. A publikált tanulmány az előadás javított, bővített és átdolgozott változata.

PARÁDI József: A dualizmuskori és a két világháború közötti Magyar Királyság határörizete. Rendvédelem-történeti Füzetek (Acta Historiae Praesidii Ordinis), XXIV.évf. (2014) 39-40-41-42.sz. 71-80.p. HU-ISSN 1216-6774.

PARÁDI József: A hátország rendvédelme 1914-1918. 108-124.p. In SzIDIROPUlosz Archimédesz (szerk.): Trianoni Szemle Évkönyv. VII. évfolyam. Budapest, 2015, Trianoni Kutatóintézet Közhasznú Alapítvány. 311 p. HU-ISSN 2060-2502.

PARÁDI József: A katonailag szervezett örtestület és a polgári örtestület. Rendvédelem-történeti Füzetek (Acta Historiae Praesidii Ordinis), XXV.évf. (2015) 43-44-45-46.sz. 77-84.p. HU-ISSN 1216-6774.

PARÁDI József: Határrendőrség a történelmi Magyarországon 19061918. Rendvédelem-történeti Füzetek (Acta Historiae Praesidii Ordinis), XXVI.évf. (2016) 51.sz. 43-56.p. HU-ISSN 1216-6774.

PARÁDI József: Karhatalom a polgári magyar állam rendvédelmében 1867-1945. Rendvédelem-történeti Füzetek (Acta Historiae Praesidii Ordinis), XXVI.évf. (2016) 52.sz. 83-94.p. HU-ISSN 1216-6774. 89.p.

SALAMON Iván: A pénzügyőri egyenruha történetéből 1868-1947. Rendvédelem-történeti Füzetek (Acta Historiae Praesidii Ordinis), III.évf. (1993) 4.sz. 170-183.p. HU-ISSN 1216-6774. A tanulmány korábbi változata 1991. november 19-én, Budapesten hangzott el a Szemere Bertalan Magyar Rendvédelem-történeti Tudományos Társaság által szervezett magyar rendvédelem-történeti tudományos konferencia-sorozatnak a „Tradíció és korszerüség” címü III. konferenciáján. A publikált tanulmány az előadás javított, bővített és átdolgozott változata.

Tо́тн László: A képviselőházi őrség születésének története. Rendvédelem-történeti Füzetek (Acta Historiae Praesidii Ordinis), IV.évf. (1994) 5.sz. 36-41.p. HU-ISSN 1216-6774. A tanulmány korábbi változata 1993. szeptember 21-én, Budapesten hangzott el a Szemere Bertalan Magyar Rendvédelem-történeti Tudományos Társaság által szervezett magyar 
Vedó: A Magyar Királyi Csendőrség karhatalmi tevékenységének szabályozása a dualizmus idején.

(11.;)

VEDÓ Attila: A Magyar Királyi Csendörség karhatalmi fellépésének gyakorlata.

(11.;)

\section{REGISZTRÁLT KÉZIRATOK}

PARÁDI: A dualista Magyarország határörizete 1867-1914.

(51.;52.;53.;)

\section{JOGSZABÁLYGYÜJTEMÉNYEK}

A Magyar Királyi Pénzügyőrség szervezete és szolgálata iránti szabályok.

(8.;)

\section{JOGSZABÁLYOK}

1723/I.tc.

(3.;)

1723/II.tc.

1867/XII.tc.

Nr.146/1867.

(2.;)

1867/XVI.tc.

(4.;)

1868/XI.tc.

(7.;)

1868/XIV.tc.

(7.;)

1868/XVI.tc.

(7.;)

1868/XIX.tc.

(7.;)

$1868 /$ XX.tc.

(7.;)

$1878 /$ XX.tc.

(4.;)

1878/XXI.tc.

(4.;)

1881/II.tc.

(15.;35.;)

1881/III.tc.

(15.;35.;)

1881/XXI.tc.

1882/XVI.tc.

(4.;)

1882/XVIII.tc.

(7.;)

1887/XXIV.tc. rendvédelem-történeti tudományos konferencia-sorozatnak a „Háború, forradalom, trianon" című V. konferenciáján. A publikált tanulmány az előadás javított, bővített és átdolgozott változata.

VEDó Attila: A Magyar Királyi Csendőrség karhatalmi tevékenységének szabályozása a dualizmus idején. Rendvédelem-történeti Füzetek (Acta Historiae Praesidii Ordinis), XXIII. évf. (2013) 31-32-33-34.sz. 185196.p. HU-ISSN 1216-6774.

VEDÓ Attila: A Magyar Királyi Csendőrség karhatalmi fellépésének gyakorlata. Rendvédelem-történeti Füzetek (Acta Historiae Praesidii Ordinis), XXIV.évf. (2014) 39-40-41-42.sz. 143-154.p. HU-ISSN 1216-6774.

PARÁDI József: A dualista Magyarország határőrizete 1867-1914. Bölcsészdoktori disszertáció (ELTE BTK). Kézirat. Budapest, 1985. 162 p.

A Magyar Királyi Pénzügyörség szervezete és szolgálata iránti szabályok. Budapest, 1868, Magyar Királyi Egyetemi Nyomda. 160 p. /A pénzügyi törvények és szabályok hivatalos összeállítása, 20./

1723/I.tc. az ország s az ahhoz kapcsolt részek karai és rendei Ő császári és királyi szent felségének szabadságaik s kiváltságaik atyai és legkegyelmesebb megerősítéseért $\mathrm{s}$ a karok és rendek közepette saját legszentségesb személyében megjelenéseért legnagyobb köszönetet mondanak.

— 1723/II.tc. Ő császári és királyi legszentségesebb felsége fölséges osztrák háza nőágának Magyarország Szent Koronájában s a régtől fogva hozzákapcsolt részekben való folytonos királyi örökösödéséről.

1867/XII.tc. a Magyar Korona országai és az Ö Felsége uralkodása alatt álló többi országok között fennforgó közös érdekủ viszonyokról, s ezek elintézésének módjáról.

- Nr.146/1867. Gesetz vom 21. Dezember 1867. 401-406.p. Betreffend die allen Ländern der österreichischen Monarchie gemeinsamen Angelegenheiten und die Art ihrer Behandlung. Reichs - Gesetz - Blatt für das Kaiserthum Österreich, (1867).

— 1867/XVI.tc. a magyar korona országai és Ö Felsége többi királyságai és országai közt kötött vám- és kereskedelmi szövetségröl.

1868/XI.tc. a sójövedék iránt.

1868/XIV.tc. a dohányjövedék iránt.

1868/XVI.tc. a szeszadóról.

1868/XIX.tc. a söradóról.

1868/XX.tc. a czukoradó iránt.

1878/XX.tc. a Magyar Korona országai és Ö Felsége többi királyságai és országai közt kötött vám- és kereskedelmi szövetségröl.

1878/XXI.tc. az osztrák-magyar vámterület általános vámtarifájáról.

1881/II.tc. a csendőrség legénységi állományának a kiegészítéséről.

1881/III.tc. a közbiztonsági szolgálat szervezéséről.

1881/XXI.tc. a Budapest-fővárosi rendőrségről.

1882/XVI.tc. az osztrák-magyar vámterület általános vámtarifájáról.

1882/XVIII.tc. az ásványolajvám felemeléséről és az ásványolaj adóról.

1887/XXIV.tc. az 1878/XX.tc.-be iktatott vám- és kereskedelmi szövetség meghosszabbításáról. 
1887/XXV.tc.

(4.;)

1889/XVI.tc.

(4.;)

1897/VIII.tc.

1898/I.tc.

(4.;)

1899/XXX.tc.

(4.;)

1903/VI.tc.

(44.;)

1903/VIII.tc.

(13.;38.;)

1907/LIII.tc.

(4.;)

1912/LXIII.tc.

(40.;)

1912/LXVII.tc.

(21.;)

1916/XXXVII.tc.

(14.;)

1917/XVII.tc.

(4.;)

50 431/1891. (VII. 1.) BM.r. (37.;)

5 692/1905. (XII.29.) ME.r. (13.; 38.;)

91 000/1905. (XII. 29.) BM.kr. (38.;)
1887/XXV.tc. az osztrák-magyar vámterület általános vámtarifájáról szóló 1882/XVI.tc. módosításáról.

1889/XVI.tc. a Fiume és Trieszt szabadkikötők területének az osztrákmagyar általános vámterületbe való beolvasztására nézve az 1887/XXIV.tc. 2. §-ában kitüzött határidőnek elhalasztásáról.

1897/VIII.tc. az 1878/XX.tc.-be iktatott és az 1887/XXIV.tc-kel meghosszabbított vám- és kereskedelmi szövetség VI. czikkelyének módosításáról.

1898/I.tc. a vám- és bankügyeknek, valamint ezekkel összefüggő némely kérdésnek ideiglenes szabályozásáról.

1899/XXX.tc. a vám- és kereskedelmi viszonyokról és ezekkel összefüggő némely kérdésnek a rendezéséröl.

1903/VI.tc. az útlevélügyröl.

1903/VIII.tc. a határrendőrségről.

1907/LIII.tc. az autonóm vámtarifáról.

1912/LXIII.tc. a háború esetére szóló kivételes intézkedésekről.

1912/LXVII.tc. a képviselőházi őrség felállításáról.

1916/XXXVII.tc. a Fiumei Magyar Királyi Állami Rendőrségről.

1917/XVII.tc. a kölcsönös kereskedelmi és forgalmi viszonyoknak az Ö Felsége uralkodása alatt álló többi országokkal való ideiglenes szabályozása iránt 1917. évi november 18.-án kötött szerződés beczikkelyezéséről.

50 431/1891. (VII. 1.) BM.r. I. Besztercze-Naszód, II. Maros-Torda, III. Csik, IV. Háromszék, V. Brassó, VI. Fogaras, VII. Szeben, VIII. Hunyad és IX. Krassó-Szörény vármegye közönségéhez intézett rendelete, az 1888. évi XIV. törvényczikkel beczikkelyezett magyar-román határegyezmény alapján kiadott határőrizeti utasitás tárgyában. Magyarországi Rendeletek Tára, XXV.évf. (1891) L.füzet. 879-902.p.

5 692/1905. (XII.29.) ME.r. a határrendőrségről szóló 1903/VIII.tc. életbe léptetéséröl. Magyarországi rendeletek Tára, XXXIX.évf. (1905) I.füzet. 1455.p.

91 000/1905. (XII. 29.) BM.kr. valamennyi törvényhatósághoz Fiume város kivételével a határrendőrségröl szóló 1903/VIII.tc. életbe léptetésének a végrehajtásáról.

Magyarországi rendeletek Tára, XXXIX.évf. (1905) I.füzet. 1455-1541.p. 
I.sz. melléklet

\section{A magyar határőrizetben szolgálatot teljesítő rendvédelmi testületek} az I. világháború elött.

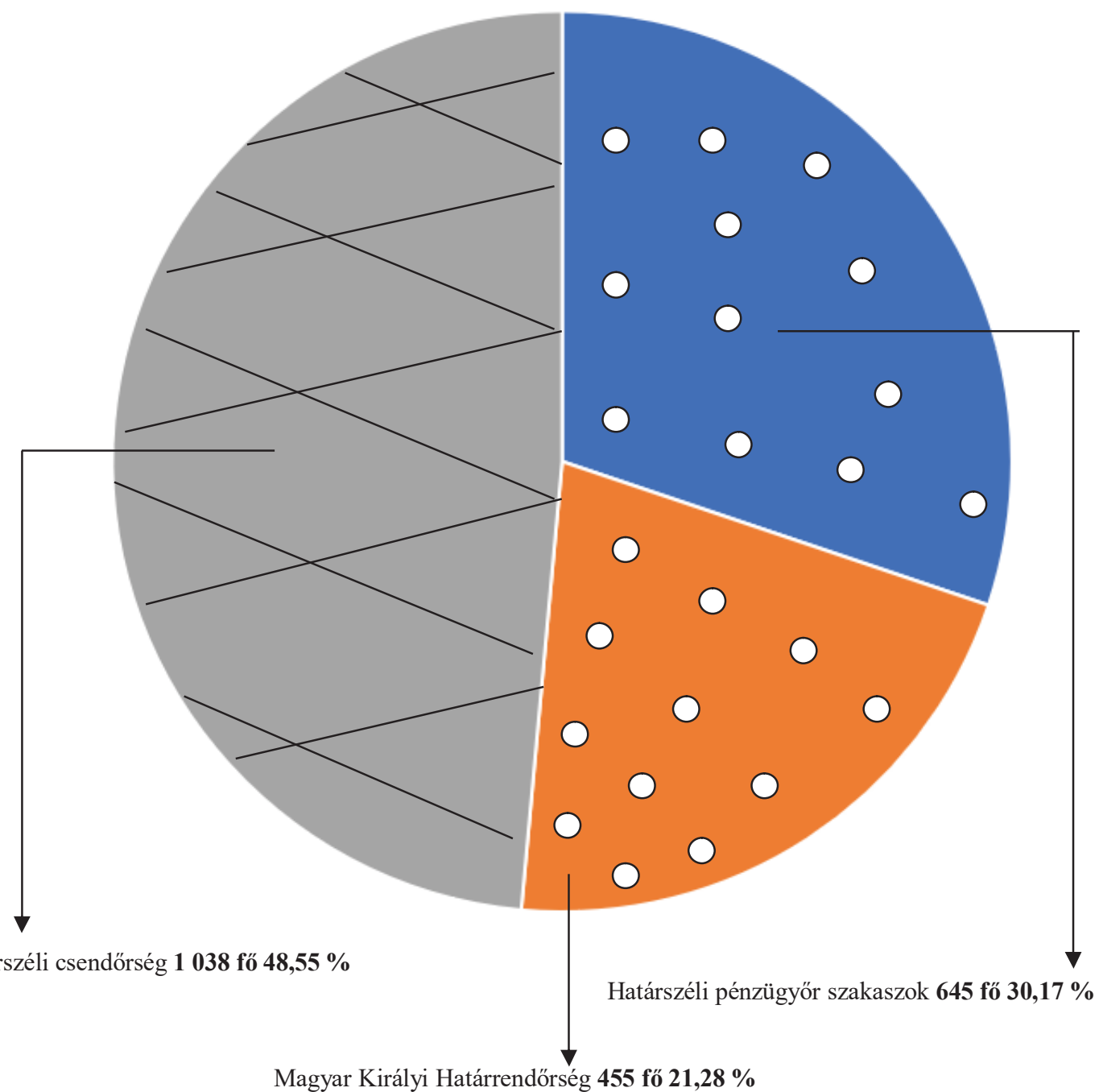

Magyar Királyi Határrendőrség 455 fö 21,28 \%

Jelmagyarárzat:

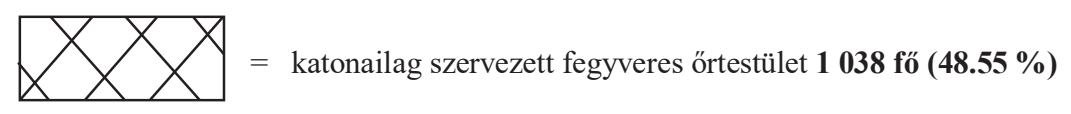

$\mathrm{O}_{\bigcirc} \bigcirc \mathrm{O}=$ polgári fegyveres örtestület 1100 fö $(\mathbf{5 1 , 4 5} \%)$

Forrás ! PARÁDI József: A magyar határőrizet a második világháború kitöréséig 1867-1939. 492.p. In BoDA József — IsASZEGI János — PÓSÁN László - VesZPRÉMY László (szerk.): Őrzők vigyázzatok a határra! Határvédelem, határőrizet, határvadászok a középkortól napjainkig. Budapest, 2017, Zrínyi Kiadó. 910 p. HU-ISBN 9789633275603. 